\title{
КЛЮЧОВІ ОСОБЛИВОСТІ АНАМНЕЗУ ХВОРИХ ІЗ ПОСТТРАВМАТИЧНИМИ ПОСТКОМАТОЗНИМИ ТРИВАЛИМИ РОЗЛАДАМИ СВІДОМОСТІ
}

\begin{abstract}
Резюме. Проблематика черепно-мозкового травматизму й надалі набуває як медичної, так і соціальної значущості через високі показники інвалідизації та летальності. Нагальною потребою є подальше вивчення причин, епідеміології та клінічних варіантів тяжкої черепно-мозкової травми (ЧМТ), наслідками якої $є$ не лише неврологічні розлади, когнітивні чи психологічні диссуннції, а й тривалі розлади свідомості. Тому продовження пошуку нових можливостей ефективного лікування та виходжування хворих із тривалими розладами свідомості після тяжкої ЧМТ не втрачає своєї актуальності.

Мета дослідження - проаналізувати ключові анамнестичні фрактори та вивчити взаємозв'язок між причинами, клінічними варіантами тяжкої ЧМТ, глибиною коми та синдромами посткоматозного порушення свідомості.

Матеріали і методи. В основу роботи покладено результати діагностики, реабілітації та відновного лікування 220-ти хворих із постткоматозними тривалими розладами свідомості після тяжкої ЧМТ. Опис клініко-неврологічної картини посткоматозного порушення свідомості у пацієнтів після тяжкої ЧМТ проводили залежно від клінічної фоорми її тяжкості й глибини травматичної церебральної коми, що мали різну за виразністю і подібну за семіотикою (ознаками) неврологічну симптоматику, проте на момент включення хворого в дослідження, а потім у ході реабілітаційного лікування, в основному визначали стадію відновлення посткоматозного розладу свідомості.
\end{abstract}

Результати досліджень та їх обговорення. Головну увагу приділено анамнестичним даним щодо клінічної форми ЧМТ та рівня глибини травматичної коми як ключових факторів впливу на розвиток тривалих посткоматозних порушень свідомості у пацієнтів, яким і надалі застосовували методи медичної (фізичної) реабілітації. Розкрито причини травматизму, проаналізовано варіанти поєднання клінічних фоорм тяжкої ЧМТ у пацієнтів із посткоматозними порушеннями свідомості, досліджено залежності між ними. У дослідженні акцентується увага на тому, що у більшості травмованих хворих помірна кома (кома I) була проявом тяжкого забою головного мозку, поєднаного зі стисненням головного мозку субдуральною, епідуральною гематомою, фрагментами стисненого перелому кісток склепіння черепа. Навіть при дисузному аксональному пошкодженні (ДАП) незначно переважали пацієнти, яким діагностовано кому І. разом з тим, глибока кома, незважаючи на відмінні числові значення кількості пацієнтів, у яких її виявлено, мала аналогічну закономірність залежності від поєднаних клінічних фоорм тяжкої ЧМТ і тому так само часто спостерігалася саме при тяжкому забої головного мозку, поєднаному зі стисненням головного мозку вищеописаними чинниками, залишаючи на другому місці забої головного мозку з лінійними переломами кісток склепіння та основи черепа (з епідуральними нашаруваннями крові). I зовсім відмінна ситуація з термінальною (позамежовою) комою, яку діагностовано більшості пацієнтів, була проявом ізольованого ДАП і його варіантами в поєднанні зі стисненням головного мозку епідуральною гематомою та фррагментами стисненого.

Висновки. Саме тяжкі забої головного мозку зі стисненням його різними окремими фракторами є найчастішими органічними субстратами посткоматозного порушення свідомості, незалежно чи була діагностована кома I, чи кома II, якщо ії тривалість становила більше 10 діб. Ізольоване чи поєднане ДАП у більшості випадків, порівняно з іншими клінічними фрормами тяжкої ЧМТ, мало симптоматику коми III. I якщо додати дорожньо-транспортну пригоду (ДТП), як головну причину ДАП, то кома III, як прояв крайнього ступеня тяжкості ЧМТ, була найтиповішою для такого виду травмування, яке, у свою чергу, призвело до того, що більшість хворих, яка вийшла з коми III, все одно залишилась у вегетативному стані, незважаючи навіть на тривале інтенсивне відновне лікування та реабілітацію.

Ключові слова: клінічні фрорми черепно-мозкової травми; дтП; дифузне аксональне пошкодження; забій головного мозку; кома; посткоматозні порушення свідомості.

ВСТУп Проблематика черепно-мозкового травматизму в XXI ст. продовжує набувати як медичної [29], так і соціальної [43] значимості через високі показники інвалідизації та летальності [30-32, 35]. Нагальною залишається потреба подальшого вивчення причин, епідеміології [1, $2,10,19]$ та клінічних варіантів тяжкої черепно-мозкової травми (ЧМТ) [28, 49], наслідками якої є не тільки грубі неврологічні розлади, когнітивні чи психологічні дисфрункції [27], а й тривалі розлади свідомості, котрі найбільше знижують якісь життя травмованих [14, 34, 36, 49].

Разом із досягненнями у діагностиці $[9,16,23,44]$, реанімації, інтенсивній терапії [15, 41], нейрохірургії [6, $12,33]$ зросла кількість тих, хто вижив [8, 12, 13], навіть із украй тяжкими клінічними фрормами черепно-мозкової травми $[17,18,25,46,47]$, що закономірно збільшило відсоток хворих із постравматичними посткоматозними тривалими розладами свідомості [26, 42], подальші відновне лікування [45] та реабілітація є вкрай складними, тривалими і не завжди успішними [4, 7, 38, 48]. Тому продовження пошуку нових можливостей для ефективного лікування та виходжування хворих із тривалими розладами свідомості згідно з класифрікацією Т. А. Добро- хотової після тяжкої ЧМТ через призму аналізу ключових анамнестичних даних $[22,24]$ не втрачає своєї актуальності [21].

Метою дослідження було проаналізувати ключові анамнестичні фрактори та вивчити взаємозв'язок між причинами, клінічними варіантами тяжкої чМТ, глибиною коми та синдромами посткоматозного порушення свідомості.

МАТЕРІАЛИ I МЕТОДИ В основУ роботи ПокЛадено аналіз 220-ти хворих із травматичними посткоматозними розладами свідомості, яких обстежували і які проходили курси нейрореабілітаційного (НР) лікування в ДУ "Інститут нейрохірургії імені акад. А. П. Ромоданова НАМН України" та в ТОВ "Науково-практичний центр нейрореабілітації "Нодус" з січня 2007 р. до липня 2018 р. включно.

Опис клініко-неврологічної картини посткоматозного порушення свідомості у пацієнтів після тяжкої ЧМТ проводили залежно від клінічної форми її тяжкості й глибини травматичної церебральної коми, що мали різну за виразністю і подібну за семіотикою (ознаками) неврологічну симптоматику, проте на момент включення хворого у дослідження, а потім у ході реабілітаційного лікування, в 
основному визначали стадію відновлення посткоматозного розладу свідомості.

Оскільки на момент початку дослідження жоден пацієнт не був доступний продуктивному вербальному контакту через основне травматичне захворювання, об'єктивне вивчення клініко-неврологічних особливостей здійснювали на підставі результатів аналізу анамнестичних даних та обстеження неврологічного статусу, окремо виділяючи основні позацеребральні травматичні прояви, особливо у випадку політравми, що мала місце у 28,18 $\%(n=62 ; N=220)$ хворих із посткоматозними порушеннями свідомості, і як відомо [3, 43, 39, 40], впливала на загальний темп відновлення. Статистичну обробку отриманих даних проводили з використанням пакета прикладних програм Statistica 6, пакета комп'ютерного аналізу Office Excel 2016, вибіркового методу: вибіркової середньої, похибки середньої; для визначення вірогідності різниці між групами - непараметричні метод: $\chi 2-$ критерій для порівняння якісних показників та t-критерій для порівняння кількісних параметрів; для порівняння двох незалежних груп - метод Манна-Уїтні [5, 20, 37].

РЕЗУЛЬТАТИ ДОСЛІДЖЕНЬ ТА ЇХ ОБГОВОРЕННЯ Досліджуючи анамнестичні дані цих хворих, встановили, що тяжка ЧМТ, унаслідок якої розвинулася тривала кома, а далі посткоматозні синдроми порушеної свідомості, була спричинена побутовим травматизмом, дорожньотранспортними пригодами (ДТП) та вогнепальною травмою. Випадків спортивного травматизму чи нещасних випадків на виробництві зафріксовано не було. Серед виявлених причин значно переважав побутовий травматизм - 55 \% (n=121) хворих, детальну структуру причин тяжкої ЧМТ подано на рисунку 1.

Побутові травми включали: падіння з висоти не більше 12 м - 51,23 \% випадків ( $\mathrm{n}=62 ; \mathrm{N}=121)$, кримінальні дії третіх осіб (побиття) - 27,28 \% хворих (n=33; $\mathrm{N}=121)$, нещасні випадки в побуті - 21,49 \% ( $n=26 ; \mathrm{N}=121)$.

Необхідно відмітити, що хоча ДТП і призводила лише до 35 \% (n=77) випадків тяжкої ЧМТ у даній дослідній групі, однак саме при цьому виді травматизму спостерігали найбільшу кількість хворих, які так і не вийшли 3 вегетативного стану, навіть після проведеного інтенсивного тривалого реабілітаційного лікування. Так, із 19 хворих (8,63 \%, N=220), які залишились у вегетативному стані на кінець дослідження, 15 отримали тяжку ЧМТ у результаті ДТП.

Вогнепальні поранення голови діагностовано у найменшої кількості хворих із посткоматозними порушеннями свідомості й становлять $10 \%(n=22 ; \mathrm{N}=220)$, однак ці клінічні випадки складають решту пацієнтів ( $n=4 ; \mathrm{N}=19)$, у котрих стан свідомості на кінець дослідження класифікували як вегетативний стан. Така мала кількість пацієнтів із даним видом тяжкої чМТ зумовлена великою летальністю постраждалих у момент травмування, або в перші дні після поранення від церебральних ускладнень $[1,2,13]$.

Виявлення в анамнезі травматичної хвороби поєднаних та ізольованих клінічних форм тяжкої ЧМТ залежно від причин, що її зумовили, подано в таблиці 1.

Як свідчать дані 3 таблиці 1, серед клінічних фрорм тяжкої ЧМТ у хворих із посткоматозними порушеннями свідомості значно переважають її поєднані варіанти (89,09 \%; n=196; N=220), причому, єдиною ізольованою клінічною фрормою тяжкої ЧМТ у досліджуваних хворих виявилося дифузне аксональне ушкодження, яке у 70,83 \% випадків ( $\mathrm{n=17;} \mathrm{N}=24)$ було спричинене ДТП. Тому ДТП
Причини тяжкої чМт, n=220

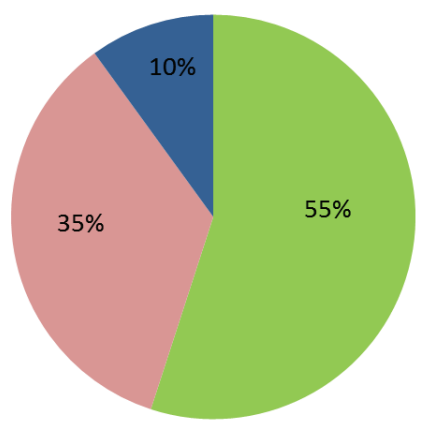

- Побутова (нещасні випадки, кримінальні дії третіх осіб, кататравма)

Дорожньо-транспортна пригода

ص Вогнепальна (бойові дії, передбачені законом)

Рис. 1. Структура причин тяжкої черепно-мозкової травми.

донині залишається найактуальнішою причиною виникнення найскладнішої $з$ усіх клінічних фрорм тяжкої ЧМТ - ДАП, унаслідок якого більшість хворих, незважаючи навіть на тривале відновне та реабілітаційне лікування, так і залишаються у вегетативному стані. При чому необхідно відмітити, що у таких випадках діагностували всі три типи ДАП J. Adams [46-48]: 1-й тип - ураження тільки гемісорер великого мозку; 2-й тип - ураження геміссрер та мозолястого тіла; 3-й тип - ураження гемісорер великого мозку, мозолястого тіла та стовбуру головного мозку.

Серед поєднаних клінічних фрорм тяжкої ЧМТ найчастіше були забій головного мозку зі стисненням головного мозку (рядки таблиці 1: 11,12,16 ): субдуральною гематомою, епідуральною гематомою та фррагментами зламаних кісток склепіння черепа, що склали 27,73\% $(n=61 ; N=220), 6,82 \%(n=15 ; N=220)$ та $15 \%(n=33 ; N=220)$ відповідно.

Наступним за частотою виявлення було поєднання забою головного мозку з лінійними переломами склепіння та основи черепа, включаючи епідуральні нашарування крові та крововиливи - 21,82 \% ( $=48 ; \mathrm{N}=220)$.

Усі інші комбінації клінічних форм не перевищили $5 \%$ від загальної кількості випадків тяжкої ЧМТ (інтервал частки: від 0,45 до 4,09).

Зважаючи на те, що вищеописані клінічні фрорми тяжкої ЧМТ в анамнезі проявлялися різною за глибиною церебральною комою, через що і випадки основної групи дослідження були поділені на відповідні підгрупи: кома I, II, III, аналіз залежності глибини коми від клінічного варіанта тяжкої ЧМТ, виявив наступні закономірності (табл. 2).

Так, за даними таблиці 2 (рядки 11,12,16), у більшості травмованих хворих помірна кома була проявом тяжкого забою головного мозку, поєднаного зі стисненням головного мозку субдуральною (20,9\% $(n=46 ; \mathrm{N}=220))$, епідуральною гематомою $(4,5 \%(n=10 ; N=220))$, фррагментами втисненого перелому кісток склепіння черепа $(10,45 \%$ (n=23; N=220). У другої за чисельністю кількості пацієнтів (рядок 7; 15,9\% (n=35; N=220) помірна кома була проявом тяжкого забою головного мозку, поєднаного з лінійними переломами склепіння й основи черепа та епідуральними нашаруваннями крові та крововиливами. Навіть при ДАП (рядок 1), незначно переважали пацієнти, у яких діагностували кому I.

Глибока кома, незважаючи на відмінні числові значення кількості пацієнтів, у яких вона виявлялася, мала аналогічну закономірність залежності від поєднаних клінічних фрорм тяжкої чМТ (коефріцієнт парної кореляції 
Таблиця 1. Варіанти клінічних форм тяжкої черепно-мозкової травми у пацієнтів із посткоматозними порушеннями свідомості залежно від причин, що іїі зумовили

\begin{tabular}{|c|c|c|c|c|c|c|}
\hline \multirow{3}{*}{ № 3/п } & \multirow{3}{*}{$\begin{array}{c}\text { Клінічна форма тяжкої ЧМТ та її } \\
\text { поєднання }\end{array}$} & \multicolumn{5}{|c|}{ Причина тяжкої ЧМТ } \\
\hline & & \multirow{2}{*}{$\begin{array}{c}\begin{array}{c}\text { вогнепальні } \\
\text { поранення }\end{array} \\
\mathrm{n}\end{array}$} & \multirow{2}{*}{$\frac{\text { дтп }}{\mathrm{n}}$} & \multirow{2}{*}{$\begin{array}{c}\begin{array}{c}\text { побутовий } \\
\text { травматизм }\end{array} \\
\mathrm{n}\end{array}$} & \multicolumn{2}{|c|}{ загальний підсумок } \\
\hline & & & & & $\mathrm{n}$ & \\
\hline 1 & ДАП & 3 & 17 & 4 & 24 & $(10,91)$ \\
\hline 2 & ДАП+ВМГ & 0 & 0 & 1 & 1 & $(0,45)$ \\
\hline 3 & ДАП+ВПЕРЕЛ & 0 & 4 & 0 & 4 & $(1,82)$ \\
\hline 4 & ДАП+ЕГ+ЛПЕРЕЛ & 0 & 1 & 0 & 1 & $(0,45)$ \\
\hline 5 & ДАП+СГ & 0 & 2 & 1 & 3 & $(1,36)$ \\
\hline 6 & ДАП+СГ+ВПЕРЕЛ & 1 & 0 & 0 & 1 & $(0,45)$ \\
\hline 7 & ЗГМ+ЛПЕРЕЛ (3 ЕНК) & 5 & 15 & 28 & 48 & $(21,82)$ \\
\hline 8 & ЗГМ+ВМГ & 0 & 3 & 6 & 9 & $(4,09)$ \\
\hline 9 & ЗГМ+ВМГ+ВПЕРЕЛ & 0 & 2 & 0 & 2 & $(0,91)$ \\
\hline 10 & ЗГМ+ВМГ+СГ & 0 & 0 & 1 & 1 & $(0,45)$ \\
\hline 11 & ЗГМ+ВПЕРЕЛ & 8 & 7 & 18 & 33 & $(15,00)$ \\
\hline 12 & ЗГМ+ЕГ & 0 & 3 & 12 & 15 & $(6,82)$ \\
\hline 13 & ЗГМ+ЕГ+ВПЕРЕЛ & 2 & 1 & 3 & 6 & $(2,73)$ \\
\hline 14 & ЗГМ+EГ $+\mathrm{C} Г$ & 0 & 1 & 3 & 4 & $(1,82)$ \\
\hline 15 & ЗГМ+ЕГ+СГ+ВПЕРЕЛ & 2 & 0 & 2 & 4 & $(1,82)$ \\
\hline 16 & ЗГМ+СГ & 0 & 21 & 40 & 61 & $(27,73)$ \\
\hline 17 & ЗГМ+СГ+ВМГ & 0 & 0 & 1 & 1 & $(0,45)$ \\
\hline 18 & ЗГМ+СГ+ВПЕРЕЛ & 1 & 0 & 1 & 2 & $(0,91)$ \\
\hline \multicolumn{2}{|c|}{ Усього, n (\%): } & 22 & 77 & 121 & 220 & $(100)$ \\
\hline
\end{tabular}

Примітка: ДАП - дисузне аксональне пошкодження; ЗГМ - забій головного мозку; СГ - субдуральна гематома; ЕГ - епідуральна гематома; ВМГ - внутрішньомозкова гематома; ВПЕРЕЛ - втиснений перелом кісток склепіння черепа; ЛПЕРЕЛ - лінійний перелом кісток склепіння та основи черепа; ЕНК - епідуральні нашарування крові та крововиливи.

Таблиця 2. Клінічні форми тяжкої черепно-мозкової травми у хворих із посткоматозними порушеннями свідомості залежно від причин, що її зумовили

\begin{tabular}{|c|c|c|c|c|c|c|}
\hline \multirow{3}{*}{ № 3/п } & \multirow{3}{*}{$\begin{array}{c}\text { Клінічна фрорма тяжкої ЧМТ та її } \\
\text { поєднання }\end{array}$} & \multicolumn{3}{|c|}{ Рівень глибини коми } & \multirow{2}{*}{\multicolumn{2}{|c|}{ Загальний підсумок }} \\
\hline & & \multirow{2}{*}{$\frac{\mathrm{I}}{\mathrm{n}}$} & \multirow{2}{*}{$\begin{array}{ll}\mathrm{II} \\
\mathrm{n}\end{array}$} & \multirow{2}{*}{$\frac{\mathrm{III}}{\mathrm{n}}$} & & \\
\hline & & & & & $\mathrm{n}$ & $(\%)$ \\
\hline 1 & ДАП & 10 & 8 & 6 & 24 & 10,91 \\
\hline 2 & ДАП+ВМГ & 0 & 1 & 0 & 1 & 0,45 \\
\hline 3 & ДАП+ВПЕРЕЛ & 2 & 0 & 2 & 4 & 1,82 \\
\hline 4 & ДАП+ЕГ & 0 & 0 & 1 & 1 & 0,45 \\
\hline 5 & ДАП+СГ & 1 & 2 & 0 & 3 & 1,36 \\
\hline 6 & ДАП+СГ+ВПЕРЕЛ & 0 & 1 & 0 & 1 & 0,45 \\
\hline 7 & ЗГМ+ЛПЕРЕЛ (З ЕНК) & 35 & 12 & 1 & 48 & 21,82 \\
\hline 8 & ЗГМ+ВМГ & 6 & 3 & 0 & 9 & 4,09 \\
\hline 9 & ЗГМ+ВМГ+ВПЕРЕЛ & 2 & 0 & 0 & 2 & 0,91 \\
\hline 10 & ЗГМ+ВМГ+СГ & 0 & 1 & 0 & 1 & 0,45 \\
\hline 11 & ЗГМ+ВПЕРЕЛ & 23 & 9 & 1 & 33 & 15,00 \\
\hline 12 & ЗГМ+ЕГ & 10 & 5 & 0 & 15 & 6,82 \\
\hline 13 & ЗГМ+ЕГ+ВПЕРЕЛ & 4 & 1 & 1 & 6 & 2,73 \\
\hline 14 & ЗГМ+EГ+CГ & 4 & 0 & 0 & 4 & 1,82 \\
\hline 15 & ЗГМ+ЕГ+СГ+ВПЕРЕЛ & 3 & 1 & 0 & 4 & 1,82 \\
\hline 16 & ЗГМ+СГ & 46 & 15 & 0 & 61 & 27,73 \\
\hline 17 & ЗГМ+СГ+ВМГ & 1 & 0 & 0 & 1 & 0,45 \\
\hline 18 & ЗГМ+СГ+ВПЕРЕЛ & 2 & 0 & 0 & 2 & 0,91 \\
\hline \multicolumn{2}{|c|}{ Усього, n (\%): } & $149(68)$ & $59(27)$ & $12(5)$ & $220(100)$ & 100,00 \\
\hline
\end{tabular}

$r=0,68=r<0,75-$ сильний кореляційний зв'язок) і тому так само часто спостерігали саме при тяжкому забої головного мозку, поєднаному зі стисненням головного мозку вищеописаними фракторами, залишаючи на другому місці забої головного мозку з лінійними переломами кісток склепіння та основи черепа (з ЕНК). 
Зовсім відмінна ситуація з термінальною (позамежовою) комою, яка у більшості пацієнтів, яку діагностували, була проявом ізольованого ДАП (рядки 1,3,4) і його варіантами в поєднанні зі стисненням головного мозку епідуральною гематомою та фррагментами втисненого перелому кісток склепіння черепа $(66,66 \%(n=8 ; N=12))$. Решта - поодинокі випадки коми III, як прояву (рядки 7,11,13) забою головного мозку з/без одномоментним/ого стисненням/ння головного мозку епідуральною гематомою та фррагментами втисненого перелому.

ВИсновКИ 1. Враховуючи виявлені анамнестичні залежності причин, клінічних фрорм тяжкої ЧМТ та глибини ком, якими вони проявлялися, встановлено, що саме тяжкі забої головного мозку зі стисненням головного мозку різними окремими фракторами $€$ найчастішими $(\alpha<0,05)$ органічними субстратами посткоматозного порушення свідомості, незалежно чи була діагностована кома I, чи кома II, якщо її тривалість становила більше 10 діб.

2. Ізольоване чи поєднане ДАП хоча майже в три рази рідше проявлялося комами I-II, проте у більшості випадків, порівняно з іншими клінічними фоорами тяжкої ЧМТ, мало симптоматику коми III.

3. У випадках ДТП, як головної причини ДАП, кома III, як прояв крайнього ступеня тяжкості ЧМТ, була найтиповішою для такого виду травмування, яке, у свою чергу, призвело до того, що більшість хворих, які вийшли з коми III, все ж залишились у вегетативному стані, незважаючи навіть на тривале інтенсивне відновне лікування та реабілітацію.

\section{СПИСОК ЛІТЕРАТУРИ}

1. Некоторые особенности огнестрельных черепно-мозговых ранений мирного времени / Н. И. Аржанов, В. М. Назаров, Т. С. Ковалева, В. В. Хоменок // Тезисы докладов I съезда нейрохирургов Российской Федерации. - Екатеринбург, 1995. - С. 27-28.

2. Бабиченко Е. И. Огнестрельные черепно-мозговые ранения мирного времени / Е. И. Бабиченко, С. З. Скулович, Б. М. Фаин // Тезисы докладов I съезда нейрохирургов Российской Федерации. - Екатеринбург, 1995. - С. 29.

3. Черепно-мозговая травма по материалам Центральной больницы г. Адена / В. П. Берснев, А. А. Шукри // Вестник хирургии им. И. И. Грекова. - 2008. - Т. 167, № 3. - С. 75-77.

4. Бицадзе А. Н. Клинико-патогенетическое обоснование и терапевтические аспекты отдаленных последствий черепномозговых травм : автореф. дисс. на соискание уч. степени канд. мед. наук : 14.00.13 / А. Н. Бицадзе. - Ленинград, 1991. - 23 с.

5. Васнев С. А. Статистика: учеб. пособ / С. А. Васнев. - М. : МГУП, 2001. - 170 с.

6. Волошин П. В. Неврологические аспекты периодизации черепно-мозговой травмы / П. В. Волошин, И. И. Шогам // Вопросы нейрохирургии. - 1990. - Вып. 6. - С. 25-27.

7. Этапы реабилитации и медико-социальная экспертиза больных с черепно-мозговой травмой : метод. рекомендации / [Л. С. Гиткина и др.]. - Минск, 1993. - 18 с.

8. Городник Г. А. Прогнозирование исхода крайне тяжелой черепно-мозговой травмы. Диагностика смерти мозга / Г. А. Городник // Травма. - 2010. - Т. 11, № 1. - С. 2-30.

9. Диагностика смерти мозга у нейрохирургических больных / Г. А. Городник [и др.] // IV з'їзд нейрохірургів України : матеріали з'їзду. - Дніпропетровськ, 2008. - С. 186.

10. Гук А. П. Епідеміологія черепно-мозкової травми в Україні / А. П. Гук // Матеріали V з'їзду нейрохірургів України, 25-28 червня, 2013. - Ужгород, 2013. - С. 38.

11. Гусев Е. И. Неврология и нейрохирургия / Е. И. Гусев, А. И. Коновалов, С. Бурд. - М., 2000. - С. 447-476.

12. Дзяк Л. А. Поэтапная модель прогноза исходов тяжелой черепно-мозговой травмы / Л. А. Дзяк, О. А. Зозуля // Медицина невідкладних станів. - 2016. - № 4. - С. 79-82.

13. Доброхотова Т. А. Исходы черепно-мозговой травмы / под ред. А. Н. Коновалова, А. Б. Лихтермана, А. А. Потапова // Нейротравматология : справочник. - М. : ИПЦ "Вазер-Ферро", 1994. - С. 84-86

14. Дралюк Н. С. Огнестрельные ранения черепа мирного времени / Н. С. Дралюк, В. К. Конев // Тезисы докладов I съезд нейрохирургов Российской Федерации. - Екатеринбург, 1995. - C. 47 .

15. Ельский В. Н. Патофизиология, диагностика и интенсивная терапия тяжелой черепно-мозговой травмы / В. Н. Ельский, А. М. Кардаш, Г. А. Городник // Руководство для врачей / под ред. В. И. Черния. - Донецк : Изд-во ДГМУ, 2004. - 200 с.

16. Жарикова Е. В. Диагностика и лечение огнестрельных ранений мирного времени / Е. В. Жарикова, Ю. С. Иоффре // Тезисы докладов I съезда нейрохирургов Российской Федерации. - Екатеринбург, 1995. - С. 50.

17. Зайцев О. С. Нейрореаниматология. Выход из комы (терапия посткоматозных состояний) / О. С. Зайцев, С. В. Царенко. - М. : Литасс, 2012. - С. 7-27.

18. Зайцев О. С. Нейрореаниматология. Выход из комы (терапия посткоматозных состояний) / О. С. Зайцев, С. В. Царенко. - М. : Литасс, 2012. - С. 24-25.

19. Иргер И. М. Черепно-мозговая травма. Болезни нервной системы : руководство для врачей : в 2-х. т. / И. М. Иргер. - М., 1982. - T. 2. - С. 44-69.

20. Казинец Л. С. О некоторых формальных приемах индексного анализа / Л. С. Казинец // Статистика. - 2001. - № 12. C. 27-30.

21. Каримов Р. Х. Эпидемиологические аспекты своевременности оказания медицинской помощи пострадавшим с черепномозговой травмой / Р. Х. Каримов, В. И Данилов, В. П. Панкова // Неврологический вестник. - 2006. - Вып. 1-2. - С. 43-48.

22. Классификация болезней нервной системы / под ред. Н. Г. Дубовской. - М., 2002. - С. 154.

23. Кулик О. В. Оцінка інорормативності нейрофрізіологічних методів діагностики стану сенсомоторної системи хворих у підгострому періоді тяжкої черепно-мозкової травми / О. В. Кулик, А. І. Третьякова // Український нейрохірургічний журнал. - 2016. - № 1. - C. 67-72.

24. Курако Ю. Л. О синдромах восстановительного и резидуального периода травматической болезни головного мозга / Ю. Л. Курако, В. Е. Волянский // Врачебное дело. - К., 1980. № 2. - С. 87-92.

25. Лихтерман Л. Б. Принципы современной периодизации черепно-мозговой травмы / Л. Б. Лихтерман // Вопросы нейрохирургии. - 1990. - Вып. 6. - С. 13-16.

26. Мещеряков С. В. Прогнозирование исходов тяжелой черепно-мозговой травмы у детей : дисс. ... канд. мед. наук : 14.01.18 / С. В. Мещеряков. - М., 2017. - 145 с.

27. Михайленко А. А. Клинико-патогенетические варианты отдалённых последствий закрытой травмы головного мозга / А. А. Михайленко, Д. Е. Дыскин, А. Н. Бицадзе // Журнал невропатологии и психиатрии им. С. С. Корсакова. - 1993. - Т. 93, № 1. - C. 39-42.

28. Никифоров А. С. Клиническая неврология : учебник : в 3 т. / А. С. Никифоров, А. Н. Коновалов, Е. И. Гусев. - М., 2004. T. 3. - C. 41.

29. Одинак М. М. Классисрикация и клинические проявления последствий черепно-мозговых травм / М. М. Одинак, А. Ю. Емельянов // Военно-медицинский журнал. - 1998. - № 1. - C. $46-51$.

30. Педаченко $€$. Г. Сучасні підходи та інноваційні технології в лікуванні черепно-мозкової травми / Є. Г. Педаченко // Мате- 
ріли V з'їзду нейрохірургів України, 25-28 червня 2013. - Ужгород, 2013. - С. 52-53.

31. Черепно-мозкова травма: сучасні принципи невідкладної допомоги : навч.-метод. посіб. / Є. Г. Педаченко, І. П. Шлапак, А. П. Гук, М. М. Пилипенко. - К. : Варта, 2007. - 311 с.

32. Полищук Н. Е. Унификация объема диагностики и медицинской помощи больным с черепно-мозговой травмой / Н. Е. Полищук, С. Ю. Рассказов // Український нейрохірургічний журнал. - 2000. - № 1 (9). - С. 73-77.

33. Потапов А. А. Хирургическое лечение больных с проникающими огнестрельными черепно-мозговыми ранениями / А. А. Потапов, Г. Г. Шагинян, С. А. Еолчнян // Тезисы докладов І съезда нейрохирургов Российской Федерации. - Екатеринбург, 1995. - С. 94-95.

34. Руководство по врачебно-трудовой экспертизе / под ред. Ю. Д. Арбатской. - М., 1981. - Т. 2. - С. 395-429.

35. Смычек В. Б. Современная классификация черепно-мозговой травмы / В. Б. Смычек, Е.Н.Пономарева // Медицинские новости. -2012 . - № 1. - С. 17-22.

36. Справочник по медико-социальной экспертизе и реабилитации / под ред. М. В. Коробова, В. Г. Помникова. - СПб., 2003. - C. $486-494$.

37. Статистика : підручник / [С. С. Герасименко, А. В. Головач, А. М. Єріна та ін.] ; за наук. ред. С. С. Герасименка. - 2-ге вид., перероб. і доп. - К. : КНЕУ, 2000. - 467 c.

38. Тяжелая черепно-мозговая травма: структура осложнений и летальности / В. К. Орлов, Ф. А. Фархат, А. И. Аверочкин [и др.] // Материалы III съезда нейрохирургов России, 4-8 июня, 2002. - СПб., 2002. - С. 54-55.

39. Феськов А. Э. Практическое значение прогнозирования при политравме / А. Э. Феськов, В. В. Никонов // Проблеми військової охорони здоров'я : збірник наукових праць Української військово-медичної академії. - К., 2002. - Вип. 11. - С. 93-98.

40. Состояние оказания помощи пострадавшим с политравмой (проблемные вопросы и перспективы развития) / Н. И. Хвисюк,
В. Г. Рынденко, А. Е. Зайцев, В. В. Бойко // Политравма. Неотложная медицинская помощь : сборник статей Харьковской городской клинической больницы скорой неотложной медицинской помощи им. проф. А. И. Мещанинова. - Харьков, 2003. С. 97-101.

41. Принципы и методы диагностики и интенсивной терапии тяжелой черепно-мозговой травмы : метод. рекоменд. I [В. И. Черний, А. М. Кардаш, Г. А. Городник и др.]. - Донецк, 2003. -58 C.

42. Черній В. І. Головний мозок при термінальному стані / В. І. Черній, А. І. Шевченко, Г. А. Городник. - Донецьк : Наука і освіта, 2000. - 220 с.

43. Чмелев В. С. Экономические последствия тяжелого сочетанного черепно-мозгового травматизма и организация экстренной нейрохирургической помощи пострадавшим в Московской области / В. С. Чмелев, А. Н. Гуров // Проблемы управления здравоохранением. - 2007. - № 3. - С. 51-57.

44. Чобулов А. Огнестрельные ранение черепа и головного мозга : метод. рекоменд. / А. Чобулов, Б. Нурханов. - Душанбе, 2000. - C. $15-28$.

45. Шагинян Г. Г. Диагностика и комплексное лечение осложнений и последствий огнестрельных черепно-мозговых ранений мирного времени : дисс. ... д. мед. наук / Г. Г. Шагинян. - М., 2000. - C. 360.

46. Diffuse axonal injury due to nonmissile head injury in humans: an analysis of 45 cases / J. H. Adams, D I. Graham, L. S. Murray [et al.] // Ann. Neurol. - 1982. - Vol. 12. - P. 557-563.

47. Diffuse axonal injury: definition, diagnosis and grading/ J. H. Adams, D. Doyle, I. Ford [et al.] // Histopathology. - 1989. Vol. 15. - P. 40-59.

48. Adams J. H. The neuropathology of the vegetative state after acute brain insult / J. H. Adams, D. I. Graham, B. Jennett // Brain. - 2000. - Vol. 123. - P. 1327-1338.

49. Plum F. The Diagnosis of Stupor and Coma / F. Plum, J. B Posner. - Philadelphia: Davis F.A. Company, 1985. - P. 96-100.

Отримано 24.10.18

Електронна адреса для листування: org@nodus.ua

\section{KEY FEATURES OF ANAMNESIS IN PATIENTS WITH POST-TRAUMATIC POST-COMA LONG-TERM DISORDERS OF CONSCIOUSNESS}

Summary. Problems of traumatic brain injury continues to acquire both medical and social significance due to high rates of disability and mortality. It is urgent to further study the causes, epidemiology and clinical variants of severe traumatic brain injuries (TBI), the consequences of which are not only neurological disorders, cognitive or psychological dysfunctions, but also long disturbances of consciousness. Therefore, the continuation of the search for new opportunities for effective treatment and outflow of patients with prolonged disorder of consciousness after severe TBI does not lose its relevance.

The aim of the study - to analyze key anamnestic factors and to investigate the relationship between causes, clinical variants of severe TBI, coma depth, and syndromes of post-motile consciousness disorder.

Materials and Methods. The work is based on the results of diagnostics, rehabilitation and restorative treatment of 220 patients with post-coma long-term consciousness disorders after severe traumatic brain injury. Description of clinical neurological picture of postcomathic disorder of consciousness in patients after severe TBI was performed depending on the clinical form of its severity and depth of traumatic cerebral coma, which had different expressiveness and similar in semiotics (signs) of neurological symptoms, but at the time of inclusion of the patient in the study, and then in the course of rehabilitation treatment, basically defining the stage of restoration of a post-comatose disorder of consciousness.

Results and Discussion. The focus is on anamnestic data on the clinical form of traumatic brain injury (TBI) and the depth of traumatic coma, as key factors influencing the development of long-term post-coma disorders of consciousness in patients, to which, later, medical (physical) rehabilitation methods were applied. The causes of injuries are disclosed, the combination of clinical forms of severe traumatic brain injury in patients with post-coma consciousness disorders is analyzed, and the linkage between them is investigated. The study focuses on the fact that in the majority of injured patients, moderate coma (coma I) was a manifestation of severe brain contusion, associated with compression of the brain with subdural, epidural hematoma, fragments of a depressed fracture of the cranial vault. Even with diffuse axonal injury (DAl), patients diagnosed with coma I were slightly predominant. At the time, deep coma, despite the different numerical values of the number of patients in whom it manifested itself, had a similar pattern of dependence on the combined clinical forms of severe TBI. Therefore, it was also often observed precisely in severe cerebral contusion associated 
with compression of the brain by the factors described above, leaving brain injuries with linear fractures of the cranial vault and skull base (with the epidural blood layers) in second place. And a very different situation is with terminal coma, which in the vast majority of patients, where it was diagnosed, was a manifestation of isolated DAI and its variants in combination with compression of the brain with epidural hematoma and fragments of a depressed fracture of the bones of the cranial vault.

Conclusions. On the basis of the obtained data, it is concluded that it is precisely severe cranial contusions with compression of the brain by various individual factors that are the most frequent organic substrates of post-coma disturbance of consciousness; coma I or coma II was independently diagnosed if its duration was more than 10 days. Isolated or combined DAI in the vast majority of cases compared with other clinical forms of severe TBI had symptoms of coma III. And if an accident, as the main cause of DAI is added, then coma III, as a manifestation of the extreme severity of TBI, was most typical for this type of injury, which, in turn, led to the fact that most patients awaken from coma III still remained in a vegetative state despite even long-term intensive restorative treatment and rehabilitation.

Key words: clinical forms of traumatic brain injury; accidents; diffuse axonal injury; brain contusion; coma; post-coma disorders of consciousness.

(). В. Кулик

Научно-практический центр нейрореабилитации “Нодус", г. Бровары

КЛЮЧЕВЫЕ ОСОБЕННОСТИ АНАМНЕЗА БОЛЬНЫХ С ПОСТТРАВМАТИЧЕСКИМИ ПОСТКОМАТОЗНЫМИ ДЛИТЕЛЬНЫМИ РАССТРОЙСТВАМИ СОЗНАНИЯ

Резюме. Проблематика черепно-мозгового травматизма преобритает все большую как медицинскую, так и социальную значимость из-за высоких показателей инвалидизации и летальности. Насущной остается потребность дальнейшего изучения причин, эпидемиологии и клинических вариантов тяжелой черепно-мозговой травмы (ЧМТ), последствиями которой является не только неврологические расстройства, когнитивные или психологические диссункции, но и длительные расстройства сознания. Поэтому продолжение поиска новых возможностей для эфрфективного лечения и выхаживания больных с длительными расстройствами сознания после тяжелой ЧМТ не теряет своей актуальности.

Цель исследования - проанализировать ключевые анамнестические факторы и изучить взаимосвязь между причинами, клиническими вариантами тяжелой ЧМТ, глубиной комы и синдромами посткоматозного нарушения сознания.

Материалы и методы. В основу работы положены результаты диагностики, реабилитации и восстановительного лечения 220-ти больных с посткоматознимы длительными расстройствами сознания после тяжелой ЧМТ. Описание клинико-неврологической картины посткоматозного нарушения сознания у пациентов после тяжелой ЧМТ проводили в зависимости от клинической формы ее тяжести и глубины травматической церебральной комы, имели разную по выразительности и сходную по семиотики (признаками) неврологическую симптоматику, однако на момент включения больного в исследование, а затем в ходе реабилитационного лечения, в основном определяли стадию восстановления посткоматозного расстройства сознания. Результаты исследований и их обсуждение. Главное внимание уделяется анамнестическим данным по клиническим формам ЧМТ и уровня глубины травматической комы как ключевым фракторам влияния на развитие длительных посткоматозных нарушений сознания пациентов, к которым в дальнейшем использовались методы медицинской (физической) реабилитации. Раскрываются причины травматизма, анализируются варианты сочетания клинических фрорм тяжелой ЧМТ у пациентов с посткоматознымы нарушениями сознания, исследуются зависимости между ними. В исследовании акцентируется внимание на том, что у большинства травмированных больных умеренная кома (кома I) была проявлением тяжелого ушиба головного мозга в сочетании со сжатием головного мозга субдуральной, эпидуральной гематомой, фррагментами вдавленного перелома костей свода черепа. Даже при диффузном аксональном повреждении (ДАП) незначительно преобладали пациенты, у которых диагностировалась кома І. В то же время глубокая кома, несмотря на другие числовые значения количества пациентов, у которых она проявлялась, имела аналогическую закономерность зависимости от совмещенных клинических фрорм тяжелой ЧМТ и поэтому так же часто наблюдалась именно при тяжелом сотрясении головного мозга в сочетании со сжатием головного мозга вышеописанными фракторами, оставляя на втором месте ушибы головного мозга с линейными переломами костей свода и основания черепа (с эпидуральными наслоениями крови). И совсем иная ситуация с терминальной (пограничной) комой, которая диагностирована у большинства пациентов, была проявлением изолированного ДАП и его вариантами в сочетании со сжатием головного мозга эпидуральной гематомой и фрагментами вдавленного перелома костей свода черепа.

Выводы. Именно тяжелые ушибы головного мозга со сжатием его разными отдельными факторами являются наиболее частыми органическими субстратами посткоматозного нарушение сознания, независимо от того была ли диагностирована кома I, или кома II, если ее продолжительность составляла более 10 суток. Изолированное или сочетанное ДАП в подавляющем большинстве случав, по сравнению с другими клиническими фрормами тяжелой ЧМТ, имело симптоматику комы III. И если добавить дорожно-транспортное происшествие (ДТП), как главную причину ДАП, то кома III, как проявление крайней степени тяжести ЧМТ, была наиболее типична для такого вида травмирования, которое, в свою очередь, привело к тому, что большинство больных, вышедших из комы III, все равно осталось в вегетативном состоянии, несмотря на длительное интенсивное восстановительное лечение и реабилитацию.

Ключевые слова: клинические формы черепно-мозговой травмы; ДТП; диффузное аксональное повреждение; ушиб головного мозга; кома; посткоматозные нарушения сознания. 